\title{
Customer Perceptions of Murabahah Financing on MSMEs
}

\section{Muflih Khallab Al Mustaqim1, Muhammad Djakfar², Misbahul Munir ${ }^{3}$}

1,2,3 Maulana Malik Ibrahim State Islamic University of Malang, Indonesia. muflih_mustaqim@yahoo.com

\begin{abstract}
Purpose - This study aims to examines the concept and implementation strategy of murabahah financing in the development of MSMEs and customer perceptions of murabahah financing at Bank BRI Syariah Jambi Branch Office.

Method-This research uses a qualitativeapproach with a type of case study. The research data were obtained by conducting in-depth interviews, observation and documentation. MethodMiles and Huberman were used as data analysis techniques by way of data reduction, data presentation and drawing conclusions / verification.
\end{abstract}

Result-Murabahah financing at BRI Syariah BankJambi Branch Office using murabahah with installments (bitsaman ajil). Thenext concept is to combine the wakalah and murabahah contracts. The strategy chosen in an effort to increase murabahah financing is to implement two strategies simultaneously, namely the internal strategy and the external strategy. Meanwhile, the perceptions of murabahah financing customers on the development of MSMEs are generally satisfied with the systems, regulations and services provided. However, customers' understanding of the concept of Islamic banking is still minimal.

Implication - Optimizing the strategy for increasing financing and disseminating the understanding of the Islamic banking concept to customers and the general public at large.

Originality - This study aims to determine the perceptions of Islamic bank customers about murabahah financing in Jambi City.

Keywords: Perception; Murabaha; Strategy; MSMEs; Case study. 
Muflih Khallab Al Mustaqim, Muhammad Djakfar, Misbahul Munir

\section{Introduction}

Talking about Islamic financing is closely related to Islamic financial institutions, especially Islamic banks. The development of Islamic banks, apart from being seen in terms of assets and income, can also be seen in terms of the number of customers. The development of the number of Islamic bank customers in Indonesia from year to year has increased, starting from 2014 the customers of Islamic Commercial Banks (BUS) totaled 12,141,264 customers. At the end of September 2017, there was an increase to reach 20,823,327 customers.

One of the provinces in Sumatra Island is Jambi Province. The development of Islamic banking in Jambi Province is quite encouraging. The growth of Islamic banks in Jambi Province as of July 2017 is around 6.42\% (Irawan, 2017). An achievement because in previous years it was $5 \%$. In September 2017, the Financial Services Authority (2017) recorded the number of Operational Headquarters (KPO) as many as 6 KPO, 19 Sub-Branch Offices (KCP) and 1 Cash Office (KK). Meanwhile, Bank Indonesia (2017) noted that the growth of Islamic banking financing in July 2017 increased by $9.42 \%$ from the previous year. The total financing that has been channeled by Islamic banks in Jambi Province until July 2017 is 2.35 trillion (Firmansyah, 2017).

The financing provided by sharia banks when viewed from the size and size of a business segment, then micro, small and medium enterprises (MSMEs) receive more financing than the business segment other than MSMEs. In 2010, MSMEs in Jambi Province received financing from Islamic banks of Rp. 52,570 billion, an increase of about 5 times from 2005 and other than that it received financing of Rp. 15,611 billion (Jambi, 2011).

The development of MSMEs and the number of workers in Jambi City has increased from year to year. The Department of Cooperatives and MSMEs of Jambi City (2017) recorded that in 2014 in Jambi City, there were 8,157 micro MSMEs with 16,394 workers, 1,763 MSMEs with 8,960 workers, and 354 MSMEs with 5,310 workers. The increase in the development of MSMEs and the number of workers starting in 2013 was 10,024 MSMEs with 29,898 
workers, in 2014 it increased by 2.5\% with 10,274 MSMEs and 30,664 workers, in 2015 it increased $2.75 \%$ with 10,556 MSMEs with 31,507 workers , in 2016 it increased 3\% with 10,868 MSMEs with 32,452 workers, and in 2017 it increased by $3.25 \%$ with 11,221 MSMEs with 33,506 workers.

Sharia financing is an activity of channeling funds carried out by Islamic banks based on the concept of Islamic banking which is based on the Islamic prohibition on lending with the expectation of a profit in the form of interest (Antonio, 1999). Funding when viewed from the contract, in Indonesia from year to year is still dominated by murabahah contracts. In general, the composition of financing channeled by sharia financial institutions, in the form of Sharia Commercial Banks, Sharia Business Units and Sharia BPRs throughout 2016, was still dominated by murabahah financing, which reached $56.78 \%$ of total financing.

Even so, the increase in sharia financing from year to year is not in line with the benefits felt by customers who use Islamic banking services (Nata, 2011). There are still many customer perceptions who complain about the financing system implemented by Islamic banks that is more burdensome for customers than conventional banks. Benefit aspects should not only be seen from a macro perspective, but also a micro perspective. Therefore, it can also be examined from individuals who use Islamic financing.

Andini and Rusdi Bedong examined customer perceptions of murabahah financing. The main reason is the ease in managing financing and a lack of understanding about the murabahah contract itself. Meanwhile, Mirawati in her research shows that customer perceptions of murabahah financing are based on moral and mutual trust, easy and fast financing accessibility and popular murabahah financing in the community.

Al Azmi and Qudsi Fauzy examined the perceptions of non-Muslim customers about murabahah financing. The results showed that their perception of the murabahah financing scheme was simple financing, promotion and mutually beneficial contracts. Even so, there are still many 
Muflih Khallab Al Mustaqim, Muhammad Djakfar, Misbahul Munir

customers who think there is no significant difference between Islamic banks and conventional banks.

Based on the foregoing, this study aims to determine customer perceptions of murabahah financing in BRI Syariah Bank Jambi Branch Office. In addition, what is the concept of murabahah financing and strategies in developing MSMEs carried out by these Islamic banks.

\section{Literature Review}

\section{Definition of Perception}

Perception is one of the important psychological aspects for humans in responding to the presence of various aspects and symptoms around them. Various experts have provided various definitions of perception, although in principle they contain the same meaning. Rakhmat (2011) defines perception as the experience of objects, events, or relationships obtained by inferring information and interpreting messages (Jalaludin, 2011). Meanwhile, according to Walgito (2002) perception is a process that is preceded by sensing, namely the stimulus process by individuals through sensory processes. However, the process does not just stop, but the stimulus is continued and the next process is a perceptual process (Walgito, 2002).

Leavitt provides an understanding of perception in a narrow and broad sense at the same time. Perception in a narrow sense is vision, how a person sees things. Meanwhile, perception in a broad sense is a view or understanding of how a person views or interprets something. The perceptual process cannot be separated from the sensing process and this process is a precursor to the perceptual process. Sensing itself can be defined as a stimulus received by the individual through a receptor called the senses. The sense organs are a link between the individual and the world at large. From the stimulus sensed by the individual, it is organized and interpreted so that the individual realizes and understands something that is sensed and then a perception is created. 


\section{Perception Factors}

The factors that influence the perception according to Rakhmat are as follows (Jalaludin, 2011): 1. Functional factors. Functional factors come from needs, past experiences and other things which include what is called personal factors. Krech and Crutchfield formulate the proposition of perception to be functionally selective. This postulate means that objects that are stressed in perception are usually objects which fulfill the objective of the individual who performs the perception; 2. Structural factors. Structural factors that determine perceptions come from outside the individual, such as the environment, culture, applicable law, values in society, which greatly affect a person in perceiving something.

According to Walgito the factors that play a role in perception can be stated as follows (Walgito, 2002): 1. Perceived object. The object gives rise to a stimulus that hits the sense organs or receptors. The stimulus can come from outside the perceiving individual, but it can also come from within the individual who directly hits the receiving nerve which acts as a receptor; 2 . Sense organs, nerves and nervous system. The sensory device or receptor is a tool for receiving stimuli, in addition, there must also be a sensory nerve as a tool to transmit the stimulus received by the receptors to the center of the nervous system, namely the brain as the center of consciousness. As a tool to create a response, a motor is needed that can shape one's perception; 3 . Attention. Attention is needed to realize or create perceptions. Attention is the main step as a preparation for making perception. Attention is the concentration or concentration of all individual activities aimed at a set of objects. These factors make individual perceptions different from one another and will affect the individual in perceiving an object, a stimulus, even though the object is really the same. The perception of a person or group can be much different from that of other people or groups even if the situation is the same.

\section{Perception Process}

According to Toha, the process of forming perceptions is based on several stages, namely: 1 . Stimulus or stimulation. The occurrence of perception begins 
when a person is exposed to a stimulus / stimulus that is present from the environment; 2 . Registration. In the registration process, a visible symptom is a physical mechanism in the form of sensing and a person's condition to be influential through their sense organs. A person can listen to or view the information sent to him, then list all the information that is sent to him; 3 . Interpretation. Interpretation is a cognitive aspect of perception that is very important, namely the process of giving meaning to the stimulus it receives. The interpretation process depends on the way of understanding, motivation, and a person's personality.

\section{Murabaha Financing}

Murabahah in the oral book of al-Arabic comes from the word "Ar-ribhu" which means (An-namaa ') which means to grow and develop. Murabahah also means "Al-irbaah" because one of the two people who transact gives benefits to the other. Meanwhile, in terms of the meaning of murabahah according to Wahbah al-Zuhaili are: "Is a sale and purchase with an initial price (cost of goods) accompanied by additional profits". This understanding is in accordance with that agreed upon by jurisprudence experts, even though the expressions used are different (Al-Jazeri, 2005).

Meanwhile, according to Antonio murabahah is the sale and purchase of goods at the original price with an additional agreed profit (Antonio, 1999). In murabaha, the seller must tell the price of the product he is buying and determine a profit level in addition. The murabahah buying and selling scheme is the most popular fiqh scheme used by Islamic banks. This is because in its definition there is an agreed profit, so the characteristic of murabaha is that the seller must inform the buyer about the purchase price of the goods and state the amount of profit added to the cost.

Murabahah transactions in Islamic banking can be done in two ways, namely: 1 . Murabaha without orders. Murabaha without an order means someone ordered or not, someone bought it or not, Islamic banks provide the merchandise. The provision of goods in this murabahah is not affected or directly related to the presence or absence of an order or buyer. Murabaha 
without orders, no matter someone ordered or not, someone bought it or not, Islamic banks always provide merchandise; 2. Murabaha by order. In this way, Islamic banks only conduct murabahah transactions when a customer orders goods so that the provision of new goods is made when there is an order. Both parties will end the sale after the ownership of the asset moves to the customer.

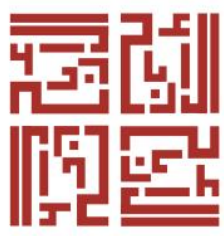

\section{Micro, Small and Medium Enterprises (MSMEs)}

Micro, Small, and Medium Enterprises (MSMEs) have different definitions in each literature according to several agencies or institutions and even laws. According to Law Number 20 of 2008 concerning Micro, Small and Medium Enterprises, MSMEs are defined as follows: 1. Micro enterprises are productive businesses owned by individuals and / or individual business entities that meet the criteria for micro enterprises as regulated in this law; 2. Small Business is a productive economic business that stands alone, which is carried out by an individual or business entity that is not a subsidiary or branch of a company that is owned, controlled, or is a part, either directly or indirectly, of a Medium or Large Business that meets the criteria of a Business Small as referred to in this Law; 3. Medium Enterprises are productive economic enterprises that are independent, carried out by individuals or business entities that are not subsidiaries or branches of companies that are owned, controlled, or are part of, either directly or indirectly, with Small or Large Businesses with total net assets or annual sales proceeds as regulated in this Law; 4. The Central Statistics Agency (BPS) provides a definition of MSMEs based on the quantity of labor, namely for home industries to have a workforce of 1 to 4 people, small businesses have a workforce of 5 to 19 people, while medium enterprises have a workforce of 20 to 19 people. 99 people.

\section{Previous Research}

Hidayati (2017) conducted a study entitled "The Influence of Customer Perceptions About Sharia BPRs on Decisions to Save at BPR Syariah Dana Amanah Surakarta City". The purpose of this study was to analyze the effect of location, belief / religiosity, service quality, knowledge, products, reputation, 
Muflih Khallab Al Mustaqim, Muhammad Djakfar, Misbahul Munir

promotion, and profit sharing on the customer's decision to save at BPR Syariah Dana Amanah Surakarta City. The results of this study prove that there is a positive and significant effect of location, belief / religiosity, service quality, knowledge, product, reputation, promotion and profit sharing on the customer's decision to save at BPR Syariah Dana Amanah Surakarta City because the p-value is smaller than a significant level of 0.05 (Nurhidayati, 2017).

Purnamasari and Arif Darmawan conducted a study entitled "Islamic Banking and Empowerment of Small Medium Enterprise". This study aims to explore the effectiveness of SME development with the role of Islamic banking in Indonesia. The results of this study indicate the development of SMEs regarding the number of business units, employment, and financing from Islamic banking shows a positive direction or increases significantly. In addition, the interaction between SMEs and Islamic banking is relatively close, but needs to be improved (Purnamasari and Darmawan, 2017).

Hassan conducted a research entitled "Entrepreneurship, Islamic Finance and SME Financing. The research aims to provide information in order to improve the management and policies of Islamic banks and the desire for the government to pay more attention to Islamic banks. The results of this study indicate that Islamic finance can expand its expansion if the management of Islamic banks determines and implements rules to support the growth of SMEs through the reform of Islamic banking laws and policies.

Alhabashi conducted a study entitled "Financing for Small and Medium Enterprises: The Role of Islamic Financial Institutions in Kuwait". The study aims to evaluate how Islamic financial institutions can support SMEs in Kuwait. The results of this study indicate that access to finance in Kuwait is a major challenge for SMEs. Furthermore, collateral is one of the main problems they face from Islamic banks. The findings show that without government support, banks find it difficult to finance SMEs optimally. Financing of specialized financial institutions is more compatible in developing SMEs than Islamic banks. 
Acfira (2014) conducted a study entitled "The Influence of Customer Perceptions on Murabahah Financing (A Customer Case Study at Bank BNI Syariah Cab. Makassar)". This study aims to test empirically the effect of customer perceptions on taking financing at Islamic banks. The results of this study indicate that the variable customer knowledge (X2), service quality (X3), bank reputation (X4) and the level of margin value (X5) partially influence the taking of murabahah financing (Y) where not all variables have a positive and significant effect. The variables that have a positive effect are customer knowledge, quality and service, and bank reputation, while those that do not affect the level of the margin value. Meanwhile, customer knowledge, quality and service (Acfira, 2014).

\section{Methods}

This research uses a qualitative approach with a type of case study. Qualitative research methods are often called "naturalist research methods" because the research is carried out in natural conditions (natural setting). According to Sugiyono qualitative research methods are used to examine the conditions of natural objects. In the research method, the researcher serves as a key instrument, the data collection technique is done by triagulation (combined technique), the data analysis is inductive and the research results emphasize meaning rather than generalization (Sugiyono, 2008). Meanwhile, the type of case study research according to Muhadjir is an in-depth study of certain events, environments and situations that make it possible to reveal something.

The research location is in Jambi City. This research was conducted at the Bank BRI Syariah Jambi Branch Office and at the homes of each subject. The sampling technique used in this research was purposive sampling and snowball sampling. Purposive sampling is a technique of sampling data sources with certain considerations. This method is used to collect data about the concepts and implementation strategies of murabahah financing in the development of MSMEs. Obtaining this data is obtained from documentation and interviews with Branch Managers, Finance Support Managers and Micro 
Unit Heads of Bank BRI Syariah Jambi Branch Office. Meanwhile, snowball sampling is a sampling technique for data sources which at first the small amount has not been able to provide complete data. then you have to find other people who can be used as data sources (Sugiyono, 2008). This method is used to obtain data on the perceptions of murabahah financing customers based on data and instructions obtained from the Head of BRI Syariah Bank Jambi Branch Office which according to him is worthy of research.

This type of research data is primary data, namely data obtained from customers who use murabahah financing at the BRI Syariah Bank Jambi Branch Office. The research data were obtained by conducting in-depth interviews, observation and documentation. Researchers used the observation method involved in being at the research site, as well as interviews with informants equipped with taking photos or relevant documentation.

Data analysis techniques using methods Miles and Huberman by way of data reduction, data presentation and conclusion / verification. Checking the validity of the data using a credibility test which includes extension of observations, increasing accuracy and triangulation, external validity, reliability and confirmability (Sugiyono, 2008).

\section{Results and Discussion}

\section{Murabahah Financing Concept for Bank BRI Syariah KC. Jambi}

Murabahah financing concept at Bank BRI Syariah KC. Jambi usesmurabahah in installments (Bitsaman ajil). This concept is a system of buying and selling with the bank as the seller and the customer as the buyer with a margin that will be obtained by the bank by agreement with the customer and purchases made by the customer are made in installments.

The next concept is a combination of the wakalah and murabahah contracts. Bank BRI Syariah KC. Jambi gives an amount of money to the customer, representing the customer to buy goods in accordance with the agreement of both parties and after the customer buys these items the customer reports the goods that have been purchased to the bank along with 
proof of purchase. The merger of murabahah and wakalah agreements is enforced by considering the number of Human Resources (HR) at Bank BRI Syariah KC. Jambi, which is minimal, accelerates the purchase of goods and simplifies the process of purchasing goods if the goods purchased are items that use a certificate of ownership.

Judging from the purpose of financing, murabahah financing at Bank BRI Syariah KC. Jambi is classified as a productive financing product. Productive financing aims to enable the recipient of financing to achieve its goals that otherwise would not have been realized. Productive financing is a form of financing that aims to streamline the production process, starting from raw materials, processing and up to the process of selling finished goods. Productive financing in Islamic banks includes investment financing and working capital financing.

\section{BRI Syariah KC Bank Strategy Jambi in Murabahah Financing.}

Murabahah implementation strategy for Bank BRI Syariah KC. Jambi is divided into two, namely an external strategy and an internal strategy. The external strategy is carried out by increasing the number of customer searches and expanding the network. So that micro murabahah products can be known to the public, especially the people of Jambi City, Bank BRI Syariah KC. Jambi conducted market activities. In addition, market raiding also functions to gather prospective MSME customers. Market raiding activities are carried out in core markets and plasma markets.

Internal strategy of Bank BRI Syariah KC Jambi is carried out in the face of competition by doing the following: 1 . Ensure the products and systems used are in accordance with sharia; 2. Fast financing process; 3. Serve customers well; 4 . Honest employees; 5 . Take firm action against employees who violate the rules.

\section{Perceptions of Bank BRI Syariah KC Murabahah Financing Customers Jambi.}

Persespi of Bank BRI Syariah KC financing customers. Jambi in the development of various MSMEs. Informants as owners of MSMEs expressed 
Muflih Khallab Al Mustaqim, Muhammad Djakfar, Misbahul Munir

satisfaction with the financing that has been carried out at Bank BRI Syariah KC. Jambi either from the system, regulations, services or installments that must be paid. The main factor for customers choosing murabahah financing at Bank BRI Syariah KC. Jambi, namely four MSME owner customers who are classified as medium-sized businesses, are the factor of avoiding usury, while for the four MSME owner customers who are classified as micro and small businesses, the factor of small interest is actually a margin because micro and small business customers cannot distinguish between the concept of interest and margin in Islamic Bank.

Expressions of satisfaction conveyed by customers certainly have hopes that the BRI Syariah KC Bank. Jambi and the customers as owners of MSMEs can be more mutually beneficial. In addition to customer expectations that the Bank BRI Syariah KC. Jambi still maintains the process, system and convenience provided, customers also hope that the ceiling or amount of financing provided by Bank BRI Syariah KC. Jambi can be increased so that MSMEs owners can further develop their business. On the other hand, the owner of CV. Assalam hopes that the KC Sharia BRI Bank financing agreement. In the future Jambi can use the musyarakah contract, which he thinks is fairer and helps in running the business he is currently doing. This is because the business is already running where when using the musyarakah contract or fund participation,

Benefits felt by customers with financing from Bank BRI Syariah KC. Jambi to the development of MSMEs is increasing the stock of goods to be sold, adding business support tools, expanding and improving business premises. The development of MSMEs will increase the benefits obtained. MSME owners and customers at Bank BRI Syariah KC. Jambi in terms of installment payments runs smoothly and is not burdensome because of the balance of benefits after obtaining financing.

\section{Conclusion}

This study uses a qualitative approach with the type of case study to determine the concept of murabahah, strategies and customer perceptions of 
murabahah financing. The results of the study explained that the murabahah financing applied at BRI Syariah Bank Jambi Branch uses the murabahah bil wakalah contract. Bank BRI Syariah KC. Jambi in an effort to increase financing implements internal and external strategies simultaneously.The internal strategy is carried out by: (a) ensuring the products and systems used are in accordance with sharia, (b) fast financing processes, (c) serving customers well, (d) honest employees, (e) taking firm action against employees who violate regulations. Bank BRI Syariah KC. Jambi is implementing an external strategy by finding more customers and expanding the network. Meanwhile,customer perceptions of murabahah financing are satisfied both from the system, rules, services or installments that must be paid. The avoidance of usury is the main factor for customers choosing murabahah financing.

The monitoring process for murabahah financing must be carried out in accordance with the applicable regulations and systems. Islamic banks must further educate the public so that the concept of Islamic banking can be understood properly. This is because there are still many Islamic bank customers who still think that Islamic banks are not much different from conventional banks.

\section{References}

Acfira, L. G. (2014) Pengaruh Persepsi Nasabah terhadap Pengambilan Pembiayaan Murabahah (Studi Kasus Nasabah pada Bank BNI Syariah Cab. Makassar). UIN Alauddin Makassar. Available at: http://repositori.uin-alauddin.ac.id/5553/1/LUKYTTA GUSTI ACFIRA_opt.pdf (Accessed: 20 January 2021).

Al-Jazeri, A. (2005) Fiqh ala Madzahibi al-Arba'ah. Beirut: Dar al-Fikr. Antonio, M. S. (1999) Bank Islam Suatu Pengenalan Umum. Jakarta: Central Bank of Indonesia and Tazkia Institute.

Firmansyah, N. (2017) Pembiayaan Perbankan Syariah Mengalami Kenaikan - Tribun Jambi, Tribun Jambi. Available at: 
Muflih Khallab Al Mustaqim, Muhammad Djakfar, Misbahul Munir

https://jambi.tribunnews.com/amp/2017/09/20/pembiayaanperbankan-syariah-mengalami-kenaikan (Accessed: 20 January 2021).

Irawan, D. (2017) Meski Kecil, Perbankan Syariah Terus Tumbuh INFOJAMBI.COM, INFOJAMBI. Available at: https://infojambi.com/meski-kecil-perbankan-syariah-terustumbuh/ (Accessed: 20 January 2021).

Jalaludin, R. (2011) Psikologi Komunikasi. Bandung: PT. Remaja Rosdakarya.

Jambi, B. (2011) Proposal Pembukuan Unit Usaha Syariah Bank Jambi.

Nata, A. (2011) Studi Islam Komperhensif. Jakarta: Prenada Media Groub.

Nurhidayati, A. (2017) Pengaruh Persepsi Nasabah Tentang BPR Syariah terhadap Keputusan untuk Menabung di BPR Syariah Dana Amanah Kota Surakarta . IAIN Surakarta. Available at: https://docplayer.info/48075920-Pengaruh-persepsi-nasabahtentang-bpr-syariah-terhadap-keputusan-untuk-menabung-dibpr-syariah-dana-amanah-kota-surakarta-skripsi.html (Accessed: 20 January 2021).

Purnamasari, F. and Darmawan, A. (2017) 'Islamic Banking and Empowerment of Small Medium Enterprise', ETIKONOMI, 16(2), pp. 221-230. doi: 10.15408/etk.v16i2.5355.

Sugiyono (2008) Metode Penelitian Kuantitatif Kualitatif dan R\&D. Bandung: Alfabeta.

Walgito, B. (2002) Pengantar Psikologi Umum. Yogyakarta: Andi Offset. 